\title{
Israel Nature and Parks Authority (INPA) Biological Databases
}

\author{
Linda Olsvig-Whittaker
}

\begin{abstract}
The Israel Nature and Parks Authority Biological Databases (GIVD ID AS-IL-001) are the repository of records dating from the early 1980's until the present date. These include casual observations of vascular plants and vertebrate animals, and an assortment of survey and monitoring projects both within and outside protected areas. There are approximately one million records accumulated in the databases. All records include species name (in Latin and Hebrew), coordinates (in the New Israel Grid system), date, and observer name. These are presence-only data, e.g. the absence of a record for an area in Israel does not imply the absence of the species. There is no national inventory for vascular plants and vertebrates in Israel. Despite these handicaps, the databases form the larges single source of electronic species-level information for the Middle East. The data are accessible to the public in several interfaces, including the query system of the Global Biodiversity Information Facility at http://www.gbif.org.
\end{abstract}

Keywords: GBIF; geo-referenced data; Middle East; nature conservation; vascular plant; vertebrate.

GIVD Database ID: AS-IL-001

Last update: 2012-07-09

\section{Israel Nature and Parks Authority (INPA) Biological Databases}

Scope: Database of $>500,000$ records on plants and animals. The vegetation data include inventory and permanent plots, the latter in selected nature reserves. The time span is from 1 to 25 years.

Status: ongoing capture

Period: $1979-2010$

Database manager(s): Linda Olsvig-Whittaker (Linda.Whittaker@npa.org.il)

Owner: [NA]

Web address: http://ww2.bgbm.org/natureinfo

Availability: free upon request

Online upload: [NA]

Online search: [NA]

Database format(s): SQL, Data provided in ACCESS or EXCEL, also Export format(s): MS Access, Excel

online

Publication: [NA]

Plot type(s): normal plots; time series

Non-overlapping plots: 1,000

Total plot observations: 5,000

Plot-size range: $1-1,000 \mathrm{~m}^{2}$

Countries: IL: $100.0 \%$

Estimate of existing plots: [NA]

Number of sources: [NA]

Completeness: [NA]

Valid taxa: 2,000

Forest: [NA] — Non-forest: [NA]

Guilds: all vascular plants: $100 \%$

Environmental data: [NA]

Performance measure(s): presence/absence only: $33 \%$; cover: $33 \%$; number of individuals: $33 \%$

Geographic localisation: small grid (not coarser than $10 \mathrm{~km}$ ): $90 \%$

Sampling periods: $[N A]$

Information as of 2012-07-12; further details and future updates available from http://www.givd.info/ID/AS-IL-001

Linda Olsvig-Whittaker (linda.whittaker@npa.org.il)

Israel Nature and Parks Authority, 3 Am Ve Olamo Street, 95463 Jerusalem, ISRAEL 